\title{
O ENRIQUECIMENTO SEM CAUSA: UMA ANÁLISE HISTÓRICO-COMPARADA / THE UNJUST ENRICHMENT: A HISTORICAL AND COMPARATIVE ANALYSIS
}

\author{
Mauricio Jorge Pereira da Mota ${ }^{1}$ \\ Daniel Queiroz Pereira ${ }^{2}$
}

\begin{abstract}
RESUMO
O presente artigo busca realizar um estudo histórico e, sobretudo, comparado, centrado na noção de "circulação dos modelos", sobre o enriquecimento sem causa. Para tanto, analisarse-á, primeiramente, a responsabilidade por inadimplemento, como forma de, posteriormente, melhor caracterizar o enriquecimento sem causa no Direito Comparado, principalmente a partir da análise de sua origem nas tradições inglesa e romanista.
\end{abstract}

Palavras-chave: Direito Comparado; enriquecimento sem causa; restituição

\begin{abstract}
This article is an attempt to carry out a historical and, principally, comparative study, centered in the notion of "models circulation", about unjust enrichment. To put this into practice, we are going to analyze, first, the responsibility resulting from breach of contract, as a way to, further, better characterize the unjust enrichment in Comparative Law, based specially in the study of its origin in the English and Roman traditions.
\end{abstract}

Key-Words: Coamparative Law; unjust enrichment; restitution.

\section{$\underline{\text { I }}$ - Introdução}

O estudo do Direito Comparado ganha vulto com o advento da obra de René David sobre sistemas jurídicos comparados ${ }^{3}$. O referido texto verificou-se diferente de todos os outros

\footnotetext{
${ }^{1}$ Professor Adjunto de História do Direito da Faculdade de Direito da Universidade do Estado do Rio de Janeiro UERJ. Procurador do Estado do Rio de Janeiro. Doutor em Direito Civil pela Universidade do Estado do Rio de Janeiro - UERJ.

${ }^{2}$ Professor Assistente de Legislação Social da Universidade Federal do Estado do Rio de Janeiro - UNIRIO. Assistente de pesquisas da Editora Atlas S.A. Advogado. Bacharel, Mestre e Doutorando em Direito da Cidade pela Universidade do Estado do Rio de Janeiro - UERJ. Pós-graduado em Direito Material e Processual do Trabalho pela Universidade Gama Filho - UGF.
} 


\section{Quaestio Iuris}

manuais jurídicos até então existentes, caracterizando-se pela clareza na exposição das idéias e por partir da individualização de quatro grandes famílias de Direitos: a romano-germânica, o Direito dos países socialistas, a common law e outras concessões da ordem social e do direito ${ }^{4}$.

O manual de David permaneceu como único referencial, em matéria de comparação jurídica, no panorama europeu e mundial até o decorrer dos anos setenta, graças à aparição do não menos renomado manual de Zweigert e Kötz, publicado em alemão ${ }^{5}$ e, posteriormente, em inglês e italiano. Esta obra diferencia-se da de David, em primeiro lugar, pelo fato de ser em dois volumes, o primeiro dedicado aos grandes sistemas jurídicos contemporâneos e o segundo a uma exposição introdutória acerca dos principais institutos de Direito Privado.

Além disso, enquanto a obra de David é sempre muito discursiva e ágil, o manual de Zweigert e Kötz é, sem dúvida, rico de dados e informações, mas, por vezes, justamente por isso torna-se cansativo e menos atraente.

Independentemente de tais especificidades, prevalece nestas obras a lógica da separação em detrimento da lógica da troca e da inter-relação. Daquela época até hoje muito mudou, o estudo comparado do Direito agigantou-se em todo o mundo e a globalização deste estudo conduziu a uma profunda revisão crítica da concepção "estática” dos vários sistemas jurídicos. Deste modo, considera-se, hodiernamente, que comparar não significa fotografar diferentes realidades e colocá-las em confronto, mas sim estudá-las no decorrer de seus desenvolvimentos, nas suas trocas e inter-relações. Em poucas palavras, busca-se realizar um estudo dinâmico destas diferentes realidades, centrado na noção de "circulação dos modelos"6 e é isto que se tentará fazer no decorrer deste trabalho que versa, especificamente, sobre o enriquecimento sem causa, analisado sob uma perspectiva histórica e, sobretudo, comparada. Para tanto, cumpre, preliminarmente, tratar da responsabilidade por inadimplemento, como forma de, posteriormente, melhor caracterizar o enriquecimento sem causa no Direito Comparado, principalmente a partir da análise de sua origem nas tradições inglesa e romanista.

\section{II - A responsabilidade pelo inadimplemento}

\footnotetext{
33 DAVID, René. Traité élémentaire de Droit Civil Compare: introduction à l'étude des droits étrangers et à la méthode comparative. Paris, 1950.

${ }^{4}$ GALLO, Paolo. Introduzione al diritto comparato. v. II. Istituti giuridici. 2. ed. Torino: Giappichelli Editore, 2003, pp. 03-04.

${ }^{5}$ ZWEIGERT, KÖTZ. Einführung in die Rechtsvergleichung auf dem Gebiete des Privat-rechts, 2 vol, Tubinga, 1969, 1971; $2^{\text {a }}$ ed., 1984; $3^{\text {a }}$ ed., 1996. 6 GALLO, Paolo. "La recezione dei modelli continentali nel diritto inglese delle obbligazioni” in Studi Sacco. vol. I. Milano. 1994, p. 483.
} 


\title{
$\underline{\text { II.1 - A responsabilidade pelo inadimplemento no Code Napoleón }}$
}

O Jusnaturalismo proclamou o princípio de "nenhuma responsabilidade sem culpa" e este princípio foi concebido para qualquer tipo de responsabilidade, isto é, tanto para o ilícito civil como para o inadimplemento contratual.

O Código Napoleão ditou normas que, apenas parcialmente, eram coerentes com este princípio. Neste particular, o art. 1137 previa que "a obrigação de guardar (custodiar) a coisa [...] implica também a de empregar a diligência do bom pai de família", parecendo significar que o inadimplemento estava baseado na negligência e, por consequiência, na noção de culpa.

Por outro lado, abarcou também o referido Codex normas de alcance mais geral, que expressavam orientação diversa, inspirado em uma concepção objetiva e não subjetiva da responsabilidade contratual. Assim sendo, o art. 1147 estabelecia que o devedor estava obrigado a indenizar os danos "sempre que não provasse que o inadimplemento provinha de uma causa estranha que não pudesse ser-lhe imputada" e o art. 1.148 excluía a responsabilidade do devedor se a inexecução da prestação decorresse da "força maior ou caso fortuito". O art. 1.302, que se referia à perda de coisa determinada, objeto de uma obrigação de dar, excluía a responsabilidade se a coisa se perdesse "sem culpa do devedor", porém assinalava que "o devedor estava obrigado a provar o caso fortuito a que aduzia”, não bastando provar a ausência de culpa, isto é, sua própria conduta diligente.

Desde o princípio, a doutrina francesa consolidou uma leitura destas normas de modo a relacioná-las com o aludido princípio jusnaturalista e o fundamento da responsabilidade permanecia sendo a culpa, daí afirmar-se que o art. 1.147 introduzia

\begin{abstract}
una presunción de culpa, limitándose a invertir la carga de la prueba, de modo que la culpa continuaba siendo el fundamento de la responsabilidad contractual [...] En cambio, otros autores han acabado por admitir que, en matéria contractual, el code Napoléon no acoge el principio de la responsabilidad por culpa sino la responsabilidad objetiva, de la que el deudor solo puede liberarse com la prueba del caso fortuito, que no excluye la culpa, que es irrelevante, sino la relación de causalidad entre su comportamiento y el incuplimento (Josserand, Marton) ${ }^{6}$.
\end{abstract}

Desta forma, para compatibilizar os arts. 1.137 e 1.147, se utilizava a distinção entre obrigações de meio e obrigações de resultado. Com base nesta distinção, em se tratando de obrigação de meio, nas quais a diligência é modalidade de prestação, deve o credor, que tem o

\footnotetext{
${ }^{6}$ GALGANO, Francesco. Atlas de Derecho privado comparado. Madri: Fundación Cultural del Notoriado, 2000, p. 210.
} 


\title{
Quaestio Iuris
}

ônus de provar o inadimplemento, provar também a culpa do devedor. Já o segundo artigo aqui referido alude às obrigações de resultado em relação às quais vige uma presunção de culpa ou uma responsabilidade objetiva. Em síntese, pode-se afirmar que

La antigua idea de la culpa como fundamento de la responsabilidad tambiém resurge bajo outra perspectiva: la obligación de médios es considerada la regla, la de resultado la excepción (Mazeaud); y así la doctrina francesa confirma uno de sus tradicionales postulados, el del fundamento unitario de la responsabilidad, sea contractual o extracontractual, en todo caso basada, em principio, en la culpa (la faute es contractuelle o extracontractuelle) ${ }^{7}$.

\section{$\underline{\text { II. } 2 \text { - O desenvolvimento em outros países }}$}

A análise da responsabilidade contratual no ordenamento jurídico alemão tem como ponto de partida o sistema das Leistungsstörungen, isto é, baseia-se naqueles eventos que obstaculizam a exata execução da prestação e impedem ao credor obter sua pretensão.

Quando reconduzíveis a um ato do devedor, as chamadas perturbações do cumprimento podem dar lugar a um juízo de responsabilidade e obrigar ao devedor o ressarcimento pelo dano.

Como "perturbações do cumprimento" se qualificam, de um lado, as hipóteses, consideradas pelo BGB, da impossibilidade superveniente da prestação ( $\$ \S 275-283$ e 323325) e a mora do devedor ( $\$ \S 284-289$ e 326 ) e, de outro lado, as vicissitudes não expressamente disciplinadas pelo BGB e qualificadas pelos intérpretes como "violações positivas do contrato". Estas últimas referem-se às hipóteses de cumprimento inexato e de inadimplemento dos chamados deveres acessórios.

\begin{abstract}
Entre estos deberes accesorios a la obligación principal, cuyo incumplimento es calificado en términos de "violación positiva del contrato", pueden recordarse, por ejemplo, el deber de protección, entendido como obligación de comportarse en el desarollo de la relación obligatoria de manera que no se ocasione perjuicio a la persona y a los bienes del outro contratante, o los deberes de información y de aclaración?.
\end{abstract}

O traço característico do sistema alemão de responsabilidade contratual é, portanto, a falta de uma noção unitária de inadimplemento.

\footnotetext{
${ }^{7}$ GALGANO, Francesco. Atlas de Derecho privado comparado. Madri: Fundación Cultural del Notoriado, 2000, p. 210.9

GALGANO, Francesco. Atlas de Derecho privado comparado. Madri: Fundación Cultural del Notoriado, 2000, p. 216.
} 
No que tange à impossibilidade superveniente da prestação, a que já se aludiu, insta mencionar que deve aqui ser entendida em uma acepção objetiva. Existe, pois, quando a prestação resulta inexequiível por parte de qualquer sujeito, podendo resultar de causas físicas, como a destruição da coisa a ser entregue; de impedimentos legais, como a proibição da venda de determinada mercadoria; da necessidade de empregar meios que por seu caráter extraordinário e impraticável não podem sequer ser levados em consideração, como no exemplo da busca de um anel perdido no fundo do mar.

É alvissareiro ainda salientar que, no sistema alemão, a impossibilidade superveniente da prestação, objetiva ou subjetiva, em virtude de causa não imputável ao devedor, o exonera. O credor não mais pode exigir a prestação e, portanto, suporta o risco da impossibilidade superveniente $(\S 275 \mathrm{BGB})^{8}$.

Se a prestação, contudo, se torna impossível em virtude de um fato pelo qual o devedor está obrigado a responder, ele será responsável e deve ressarcir o credor pelo dano decorrente do inadimplemento da obrigação ( $§ 280$ BGB). O ponto central desta análise reside, pois, na individualização dos fatos pelos quais o devedor está obrigado a responder, o que o legislador previu nos $\S \S 276-278$ BGB. Considera-se, contudo, que tais normas oferecem critérios para um juízo sobre a imputação ao devedor em qualquer hipótese de perturbação do cumprimento e, portanto, se aplicam também ao atraso no cumprimento e às violações positivas do contrato.

Ainda em relação a este sistema, faz-se necessário mencionar que o princípio da responsabilidade por culpa (Verschuldensgrundsatz), previsto no $§ 276$, é a expressão da tradição romanística e convive com uma tendência inversa no sentido da objetivação da responsabilidade do devedor, como se nota, por exemplo, nos $\S \S 278,279,287$ e 300 BGB.

No sistema da common law a responsabilidade contratual assume diferente feição, isto porque a contract liability delimita um campo não totalmente coincidente com a responsabilidade contratual.

\footnotetext{
8 “La regla encuentra su correspondiente aplicación em los contratos sinalagmáticos. En esta clase de contratos el contratante que se libera de la obligación por imposibilidad sobrevenida tambiém pierde el derecho a la contraprestación (§323 BGB), según um principio que refleja la lógica del sinalagma. Por su parte, la parte acreedora de la prestación devenida imposible se libera ipso iure de su próprio deber, sin que sea necessária uma declaración de desistimiento. La imposibilidad sobrevenida de la prestación debida a causa no imputable al deudor tiene, pues, como consecuencia, la resolución del contrato con prestaciones recíprocas". GALGANO, Francesco. Atlas de Derecho privado comparado. Madri: Fundación Cultural del Notoriado, 2000, p. 218.
} 
A contract liability surge como uma breach of contract, isto é, como o não cumprimento de um contrato e, em especial, como o não cumprimento de uma promessa contratual expressa ou ainda como o não cumprimento do dever de executar o contrato conforme a boa fé.

Em contrapartida, no sistema de civil law, responsabilidade contratual é sinônimo de responsabilidade por não cumprimento de uma obrigação, qualquer obrigação, tenha surgido em virtude de um contrato, de um ato unilateral ou da lei.

Considerar que um contratante incide na breach of contract sempre significa considerálo responsável pelos danos causados, porém também significa dar à outra parte a possibilidade de eleição entre manter a pretensão de cumprimento ou reputar o contrato como discharged (desfeito), sempre que concorra para o não cumprimento de uma condition, isto é, de uma cláusula afeta à raiz do contrato. Nas palavras de Francesco Galgano,

[...] siempre que concurra el incumplimiento de una condition, es decir, de una promesa que condiciona el derecho a la contraprestación; y para identificar cuáles sean las conditions se acude a la noción de fundamental breach, en el sentido de que cuando el incumplimiento de una cláusula afecta a la raiz misma del contrato, entonces se está sin duda en presencia de una condition (Atiyah, Cheshire y Fifoot, Treitel). Hasta aqui, pues, las relaciones entre responsabilidad y resolución no son más estrechas que en civil law, y la afrimación de responsabilidad de un contratante no es necesariamente seguida de la extinción (discharge) del contrato, que no puede obtenerse ante cualquier breach of contract, sino solo ante un fundamental breach ${ }^{9}$.

Percebe-se ainda, no que diz respeito aos sistemas de common law, uma superação da antiga perspectiva segundo a qual as obrigações contratualmente assumidas eram inderrogáveis e deviam ser cumpridas inclusive diante de obstáculos insuperáveis, levando a soluções mais elásticas que permitem dar relevo a circunstâncias que possam alterar a economia do negócio.

Deste modo, a quebra do equilíbrio sinalagmático do contrato e a frustration of purpose, hipótese em que mudanças nas circunstâncias tornam irrealizável o programa econômico originariamente perseguido pelas partes, têm adquirido relevo neste sistema, permitindo, em alguns casos, a exoneração da responsabilidade do devedor, sem que com isso se abandone o panorama inicial de strict liability.

En otras palabras, quien lee en los autores ingleses o estadunidenses que la contract liability ya no es absolute no debe deducir que también haya dejado de ser strict, y se admita la liberación del deudor que pruebe que, a pesar de su esfuerzo diligente, no há conseguido superar el impedimento.

Dicha afirmación significa, sencillamente, que el principio de la inderogabilidad de las obligaciones contractuales ha admitido una serie cada vez más creciente de excepciones que han comportado una proliferación de las hipótesis de extinción del

\footnotetext{
${ }^{9}$ GALGANO, Francesco. Atlas de Derecho privado comparado. Madri: Fundación Cultural del Notoriado, 2000, pp. 226-227.
} 
contrato; la racionalización de estas hipótesis ha llevado a la elaboración de una doctrine de la impossibility (en los Estados Unidos convertida más tarde en impracticability) y de la frustation, es decir, dela extinción del contrato; teoría rápidamente extendida para abarcar las hipótesis de frustration of the common venture (o frustration of purpose), esto es, las hipóteses en las que el cambio de circunstancias hace irrealizable el programa econômico originariamente perseguido por las partes. En esta doctrine también han confluído, inevitablemente, los problemas de exoneración de responsabilidad del deudor, sin que por outra parte se viera afectado el panorama inicial de strict liability, es decir, de responsabilidade objetiva $^{10}$.

Emblemático de tais mudanças foi o caso Taylor v. Caldwell, que data de 1863 e no qual se resolveu uma controvérsia relativa à responsabilidade contratual. Caldwell havia pactuado com Taylor o uso dos Surrey Gardens e do Music Hall para quatro concertos de gala, porém uma semana antes da data estipulada um incêndio acidental destruiu por completo a sala de concertos. Taylor, que já havia realizado vultosos gastos publicitários, solicitou ressarcimento pelos danos sofridos, o que foi negado pela ausência de uma cláusula expressa sobre incêndios. O Queen's Bench considerou que o contrato não era absolute e que continha uma implied condition relativa à existência da sala e declarou sua resolução, afirmando, por consequiência, a falta de fundamento da pretensão ressarcitória.

Embora a regra dos absolute contracts já tivesse sido excepcionada em casos anteriores, este leading case foi essencial para o desenvolvimento da doctrine of frustration, que passou a permitir a exoneração do devedor nas hipóteses de destruição da coisa objeto da prestação; de impossibilidade derivada de uma proibição legal, administrativa ou judicial; e de incumprimento em razão de morte, incapacidade ou indisponibilidade física do devedor que assumiu uma obrigação personalíssima, isto é, que não pode ser realizada por outrem ${ }^{11}$.

\section{$\underline{\text { III }-\mathrm{O} \text { enriquecimento sem causa }}$}

\section{1 - Os "quase-contratos" (quasi-contracts) ingleses}

\footnotetext{
${ }^{10}$ GALGANO, Francesco. Atlas de Derecho privado comparado. Madri: Fundación Cultural del Notoriado, 2000, p. 229.

${ }^{11}$ GALGANO, Francesco. Atlas de Derecho privado comparado. Madri: Fundación Cultural del Notoriado, 2000, p. 230 .
} 
Percebe-se, deste modo, que o sistema contratual inglês era originalmente muito rígido, impossibilitando, por exemplo, que aquele que se dispusesse a confeccionar um vestido, sem previamente acordar o preço, pudesse exigir em juízo a respectiva contribuição.

Si trattava indubbiamente di uma regola palesemente iniqua.

È però solo sucessivamente allo Slade's Case che è stato possibile individuare uma soluzione anche a questo problema.

Appena sette anni dopo, nel 1609, si ammise per la prima volta il diritto di um albergatore a farsi pagare per $\mathrm{i}$ servizi prestati, anche in assenza di espressa determinazione del corrispettivo, presumendo un tacito accordo delle parti a devolvere quello che fosse stato il valore della prestazione (quantum meruit). ${ }^{12}$

Nesta esteira, nascem os "quase-contratos" ingleses, que permitem transcender as noções de breach of contract e de responsabilidade civil clássica.

Os "quase-contratos" ingleses se referem a acordos imperfeitos que, pela carência de um qualquer requisito considerado essencial, não podiam ser considerados idôneos a gerar um vínculo válido entre as partes.

Come direbbe Atiyah, nei casi di questo genere la responsabilità si basava sul ricevimento di un beneficio: benefit based liability.

Atiyah svaluta infatti il momento consensuale nella conclusione del contrato (promise based liability), ed in sua vece rivaluta o il conseguimento di un beneficio (benefit based liability), o l'affidamento oneroso, vale a dire l'assunzione di oneri da parte del destinatário della dichiarazione (reliance based liability).

Si trata a ben vedere di un tentativo di dissolvere la distinzione tradizionale tra contracts, torts e restitutions, in vista dell'elaborazione di um sistema unitário delle fonti delle obbligazioni ${ }^{13}$.

De qualquer forma, resta evidente que a lógica dos quasi-contracts ingleses difere daquela dos "quase-contratos" na tradição romanista, conforme melhor se verá adiante, já que o objetivo aqui não reside em restituir uma res determinada, de modo a restituir as partes ao status quo ante, mas sim remunerar aquele que cumpriu sua obrigação.

Embora ainda distantes da lógica atual do enriquecimento sem causa, os quasicontracts ingleses evitavam um enriquecimento injustificado de uma das partes, embora não fosse efetivamente necessário que a outra parte obtivesse uma vantagem pelo implemento da prestação. Voltavam-se, portanto, à imposição da obrigação de devolver o correspondente monetário da prestação recebida.

Posteriormente, buscou-se realizar uma unificação dos remédios restituitórios em um único contexto, qual seja, o do princípio geral que veda o enriquecimento ilícito. Neste passo, o

\footnotetext{
${ }^{12}$ GALLO, Paolo. Introduzione al diritto comparato. v. II. Istituti giuridici. 2. ed. Torino: Giappichelli Editore, 2003, pp. 211-212.

${ }^{13}$ GALLO, Paolo. Introduzione al diritto comparato. v. II. Istituti giuridici. 2. ed. Torino: Giappichelli Editore, 2003, p. 212.
} 


\section{Quaestio Iuris}

Restatement americano de 1937 enunciava, em linhas gerais, que qualquer um que enriqueça às expensas de um outro deve restituir o quanto recebido.

Mais do que isso, passa-se a exigir como pressuposto para obtenção da restituição a prova de um enriquecimento (benefit), obtido de forma injusta (unjust), às expensas de outrem (at the plaintif's expenses).

Acerca do significado de enriquecimento (benefit) afirmam os autores que

l'espressione benefit non ha un unico significato (has no single meaning), ma varia a seconda delle circostanze; in particolare si avrebbe benefit in primo luogo quando si è in presenza di un vero e proprio arrichiamento, ed in secondo luogo quando pur mancando l'arrichiamento la prestazione sai stata richiesta.

Questa duplicità di significato non è ovviamente priva di spiegazione, ove si consideri che nell'ambito della law of restitution confluiscono fattispecie eterogenee, vale a dire sia i casi che noi qualificheremmo di arricchimento senza causa in senso stretto, che quelli di indebito ${ }^{14}$.

\section{III.2 - Os "quase-contratos" na tradição romanista e a influência do Direito Canônico}

No direito romano clássico não existia uma ação de enriquecimento sem causa comparável à moderna, mas existiam vários remédios de natureza "quase-contratual"17.

A condictio constitui o arquétipo de todos os modernos sistemas de repetição do indébito. Consiste em um antigo remédio cuja função era a de possibilitar a recuperação de um bem dado em execução em decorrência de um contrato inválido. Ao comentar a origem da condictio, afirma Demètre Gerota que esta surge "comme la conséquence d'um autre príncipe de haute moralité: suum cuique tribuere ${ }^{15}$ ". Buscava, portanto, a restituição de deslocações patrimoniais que ocorrem sem uma causa (da atribuição patrimonial e de justificação do seu resultado).

[...] uma das características mais marcantes da legis actio per condictionem era a sua natureza abstrata: a base substantiva da acção, a causa debendi, não era mencionada. Esta característica conferiu-lhe uma acentuada flexibilidade. Outra nota, particularmente curiosa num domínio que depois se quis fazer assentar directamente na equidade, reside na circunstância de que se tratava aqui de uma das actiones strict

\footnotetext{
${ }^{14}$ GALLO, Paolo. Introduzione al diritto comparato. v. II. Istituti giuridici. 2. ed. Torino: Giappichelli Editore, 2003, p. 218. 17 "As origens do moderno enriquecimento sem causa no Direito Romano são, ao que parece, múltiplas. Em primeiro lugar, destacam-se as condictiones; contudo, não se reduzem àquelas, antes devem também buscar-se na actio de in rem verso, não sendo, ainda, de negligenciar [...] a influência de um outro instituto próximo, a gestão de negócios alheios, particularmente na sua modalidade de gestão imprópria de negócios". GOMES, Júlio Manuel Vieira. O conceito de enriquecimento, o enriquecimento forçado e os vários paradigmas do enriquecimento sem causa. Porto: Coimbra Editora, 1998, p. 26.

${ }^{15}$ GEROTA, Demètre G. La théorie de l'enrichissement san cause dans le Code Civil allemand. Paris: LGDJ, 1925, p. 39. 19

GOMES, Júlio Manuel Vieira. O conceito de enriquecimento, o enriquecimento forçado e os vários paradigmas do enriquecimento sem causa. Porto: Coimbra Editora, 1998, p. 28.
} 
iuris do direito romano. Importa, também, salientar que a tipologia das diferentes condictiones [...] não nos deve induzir em erro: na perspectiva clássica a condictio era um procedimento abstracto e uniforme ${ }^{19}$.

A utilização deste procedimento apareceu, pois, associada aos problemas conexos com a transmissão da propriedade, sobretudo em um sistema que admitia casos de transmissão abstrata. Isto porque a expressão "propriedade" associava, já naquela altura, dois aspectos fundamentais: o reconhecimento, pela ordem jurídica, da apropriação absoluta de um objeto material (coisa) por um indivíduo e a legitimação material, finalístico-racional, dessa apropriação.

Deste modo, os fatos que, em termos jurídicos, acarretavam uma transmissão da propriedade eram fatos que justificavam a apropriação da coisa por um novo proprietário e que justificavam essa apropriação especificamente face ao anterior proprietário. Tais fatos, designados na terminologia romana por causae, fundavam a atribuição patrimonial e justificavam o resultado final dessa atribuição. Sua ausência, em virtude do não preenchimento de certos requisitos, significava a ilegitimidade da pretensão de apropriação do destinatário da atribuição patrimonial, o que institucionalmente se traduzia em um sistema de transmissão causal na não transmissão da propriedade. Em princípio, o anterior proprietário não carecia, nesta hipótese, de tutela especial, já que dispunha da proteção da propriedade, designadamente da rei vindicatio.

Todavia, pode suceder que o substrato corpóreo da propriedade tenha sido destruído ou que a sua identidade se haja perdido, por exemplo, em virtude de a coisa ter sido consumida, objecto de confusão, acessão, etc. Nesta hipótese, impõe-se uma actio in personam, a conditio. Já neste contexto se divisa a principal função desta, a restituição de deslocações patrimoniais que ocorrem sem uma causa (da atribuição patrimonial e de justificação do seu resultado). Trata-se, em regra, de deslocações ocorridas por iniciativa de quem vem, depois, solicitar a restituição [... $]^{16}$.

O principal campo de aplicação das condictiones residia, portanto, no domínio das transmissões abstratas de propriedade, como, por exemplo, nos casos de mancipatio de determinadas coisas (as res mancipi: escravos, gado, propriedade fundiária na Itália) em que decisivo era o cumprimento de um determinado ritual pelo que o negócio assumia o caráter de

\footnotetext{
${ }^{16}$ GOMES, Júlio Manuel Vieira. O conceito de enriquecimento, o enriquecimento forçado e os vários paradigmas do enriquecimento sem causa. Porto: Coimbra Editora, 1998, p. 32.
} 


\section{Quaestio Iuris}

vol.04, nำ01. ISSN 1516-0351

um negócio real, formal e sem referência à causa material. Por conseguinte, cabia à condictio a tarefa de fazer regressar a propriedade à pessoa do queixoso, repristinando a situação anterior ${ }^{17}$.

Um outro "quase-contrato" romano que deve ser mencionado é a negotiorum gestio. Consistia em um instituto pensado a partir do mandato, que consentia na extensão da disciplina deste instituto a casos em que faltasse um prévio e expresso encargo da parte do dominus negotii ${ }^{18}$.

Os pressupostos de aplicação da negotiorum gestio eram delineados com extremo rigor, exigindo-se, “oltre alla alienità del negozio, l'absentia domini, l'utiliter coeptum, ovvero il fatto che la gestione fosse stata utilmente intrapresa a prescindere dai suoi risultati finali, ed infine l'animus aliena negotio gerendi, ovvero l'intenzione e la consapevolezza di gestire un affare altrui $^{19}$,

Este último requisito era especialmente importante de forma a possibilitar a exclusão da pretensão ressarcitória na hipótese em que, por exemplo, alguém houvesse realizado melhoramentos na propriedade de outrem pensando que esta lhe pertencia.

Nas palavras de Júlio Manuel Vieira Gomes,

Esta gestão imprópria de negócios, freqüentemente apelidada também de anômala, extraordinária ou de gestão de negócios em sentido amplo, encontra as suas origens no direito romano, muito embora já neste houvesse alguma confusão quanto à relação entre esta figura e a gestão própria de negócios; em pelo menos quatro casos afirmava-se a possibilidade da existência de uma gestão imprópria: quando o gestor administrava o negócio de um menor; quando administrasse o negócio de outrem de má fé e na mira de um benefício próprio; quando administrasse o negócio de outrem na convicção errônea de que se tratava de um negócio próprio e finalmente quando administrasse os negócios de outrem contra a proibição expressa do dominus ${ }^{24}$.

\footnotetext{
17 “[...] c'était une action qui servait subsidiairement au proprieétaire dépossédé ayant perdu le droit d'intenter la revendication. Accordée au début, dans le cas de mutuum, on l'aurait appliqué plus tard, par analogie uniquement pour sanctionner les contrats ou quasi-contrats - et vu leur caractére re, à d'autres obligations, telles que le paiement de l'indu, la datio ob causam et à toute detention illégitime”. GEROTA, Demètre G. La théorie de l'enrichissement san cause dans le Code Civil allemand. Paris: LGDJ, 1925, p. 43.

18 "Probabilmente la prima applicazioni di questo istituto si sono avute a favore di mandatari veri e propi, i quali nel corso della gestione si erano peró trovati nella necessita di discostarsi in qualche misura dalle istruzioni recevute, o ancora a compiere atti di gestione non autorizzati nell'impossibilità di mettersi in contatto con il dominus.

Si giunse cosi a configurare um istituto molto vicino, sai nei pressupposti che negli effetti, al contratto di mandato in virtù del quale il gestore aveva diritto al rimborso delle spese, e nel contempo rispondeva per le eventuali negligenze commesse nell'espletamento del suo compito". GALLO, Paolo. Introduzione al diritto comparato. v. II. Istituti giuridici. 2. ed. Torino: Giappichelli Editore, 2003, p. 220.

${ }^{19}$ GALLO, Paolo. Introduzione al diritto comparato. v. II. Istituti giuridici. 2. ed. Torino: Giappichelli Editore, 2003, p. 220. 24

GOMES, Júlio Manuel Vieira. O conceito de enriquecimento, o enriquecimento forçado e os vários paradigmas do enriquecimento sem causa. Porto: Coimbra Editora, 1998, pp. 50-51.
} 
A actio in rem verso, ao seu turno, permitia agir diretamente em face do dominus que houvesse obtido proveito do negócio realizado por seu pupilo ou escravo (alguém sob seu poder), mas apenas nos limites do efetivo enriquecimento ${ }^{20}$. Nas palavras de Paolo Gallo:

Ogni cosa acquistata dagli schiavi o dai loro figli che non fossero sui iuris, entrava automaticamente a far parte del patrimonio del pater famílias.

Tutto questo si riferiva però esclusivamente al lato attivo, um figlio e tanto meno uno schiavo non poteva cioè assumere impegni vincolanti anche per il pater.

A partire da una certa epoca per ovviare a questo stato di cose e per escludere che un dominus potesse sfuggire ai suoi impegni semplicemente non stipulando i suoi affari personalmente, i giureconsulti romani cercarono di scogitare corretivi ${ }^{21}$.

Insta ainda mencionar que é essencial na compreensão do enriquecimento sem causa a obra dos compiladores bizantinos, já que “em nenhum outro domínio do direito privado os compiladores se sentiram tão livres como nos textos atinentes ao enriquecimento injustificado $^{22,}$.

A atitude dos compiladores parece ter sido influenciada por duas ordens de fatores. A primeira delas consiste na influência do Cristianismo, com o acento nas idéias da humanidade, generosidade e caridade. Por outro lado, verificou-se o desaparecimento do sistema pretoriano de remédios e a criação de uma estrutura unitária e hierárquica de tribunais responsáveis, face ao Imperador, tornando supérfluas muitas das distinções entre as condictiones.

Deste modo, constatou-se uma generalização e abstração progressivas, responsáveis pela conversão das condictiones em uma figura unitária e universal: o enriquecimento injustificado.

Após alguns séculos, a obra dos compiladores bizantinos teve uma influência determinante na reconstrução do enriquecimento sem causa operada quando da redescoberta do direito romano. De fato, os glosadores não podiam suspeitar da existência de numerosas

\footnotetext{
${ }^{20}$ Por ação dos glosadores, ampliaram-se as hipóteses em que se podia invocar a actio de in rem verso. Nas palavras de Júlio Manuel Vieira Gomes, "a actio de in rem verso é uma situação tipicamente triangular em que uma pessoa sem poderes de representação (e frequentemente, dir-se-á, como gestor de negócios) celebra com outra um negócio para um terceiro, que aparecerá como o dano do negócio e o demandado na actio de in rem verso - responderá na medida do seu benefício, muito embora o apelo às regras da gestão de negócios possa implicar que seja suficiente um benefício inicial, uma utilidade inicial da gestão. Interferem aqui, já o dissemos, o pensamento subjacente à restituição do enriquecimento injustificado e à gestão de negócios, a tal ponto que a actio de in rem verso ora é reconduzida a um ou a outro destes vectores, representando, também, um importante factor na sua convergência - outros dirão na sua confusão - e tornando, progressivamente, mais aparentados enriquecimento sem causa e gestão de negócios". GOMES, Júlio Manuel Vieira. O conceito de enriquecimento, o enriquecimento forçado e os vários paradigmas do enriquecimento sem causa. Porto: Coimbra Editora, 1998, pp. 41-42.

${ }^{21}$ GALLO, Paolo. Introduzione al diritto comparato. v. II. Istituti giuridici. 2. ed. Torino: Giappichelli Editore, 2003, p. 221.

22 . Porto: Coimbra Editora, 1998, p. 53.
} 
interpolações, para não dizer falsificações, dos textos clássicos, e também, dado que os glosadores partiram da premissa de que o Corpus Juris representava uma espécie de súmula da sabedoria humana e que sua tarefa residia apenas em a reproduzir, com a maior fidelidade possível, através de uma análise do texto estrita, os resultados que alcançaram não podiam deixar de estar marcados pela obra de generalização dos compiladores bizantinos.

\begin{abstract}
Assim, boa parte dos desenvolvimentos ocorridos graças à obra dos glosadores ocorreu em virtude da polémica que incidiu em problemas muito específicos, geralmente problemas que poderiam ser classificados de marginais e relativamente aos quais as soluções dos textos clássicos se mostravam ambíguas ou contraditórias. Em jogo estavam, fundamentalmente, três grupos de problemas: em primeiro lugar, a realização de benfeitorias em propriedade alheia. Trata-se, efectivamente, de uma questão delicada que coloca em confronto, com toda a nitidez, interesses contrapostos - por um lado, o enriquecimento do proprietário tantas vezes manifesto (ao menos do ponto de vista do valor objectivo ou de mercado) e a circunstância de que, frequentemente, a atitude da pessoa que realizou a benfeitoria pode ficar a dever-se a um erro desculpável quanto à propriedade do bem em causa; mas, e por outro lado, a ausência de qualquer contrato ou transacção entre o proprietário e o realizador da benfeitoria tornava problemático o dever do primeiro de indemnizar (ou restituir o valor) ao segundo. Uma outra área de problemas que suscitou acesa polémica entre os glosadores respeitava àquelas situações em que, após um furto ou outro desvio de propriedade, os lucros obtidos com a sua venda acabavam por beneficiar um terceiro que não se tinha envolvido no furto. $\mathrm{O}$ terceiro grupo de casos, por seu turno, reportava-se a contratos que acabavam por redundar num benefício para um terceiro estranho à transacção: um exemplo fornecido pelos próprios glosadores era o do empréstimo a uma pessoa insolvente, mas que tinha usado a quantia mutuada para adquirir alimentos para seus filhos. Estes, vinham, mais tarde, a herdar bens da parte de sua mãe pelo que a questão que se colocava era a de saber se o mutuante poderia, face à insolvência da sua contraparte no contrato, exigir a restituição aos filhos do insolvente a quantia mutuada, já que estes haviam retirado da mesma um benefício ${ }^{23}$.
\end{abstract}

Contudo, mais do que as soluções concretas encontradas para estes problemas específicos, o que se verifica de maior relevo na obra dos glosadores é a paulatina mudança de atitude que se traduz numa crescente facilidade em invocar diretamente o princípio do enriquecimento injustificado.

Os pós-glosadores também prosseguiram nesta tendência de alargar o número restrito de situações em que, de acordo com a maioria dos glosadores, era permitida a exigência de restituição do preço, ao vendedor de coisa alheia. Por vezes, parecia estar presente um pensamento de sub-rogação, em que o preço substituía a coisa. Outras vezes, criava-se a ficção

\footnotetext{
${ }^{23}$ GOMES, Júlio Manuel Vieira. O conceito de enriquecimento, o enriquecimento forçado e os vários paradigmas do enriquecimento sem causa. Porto: Coimbra Editora, 1998, pp. 55-56.
} 


\section{Quaestio Iuris}

de que a propriedade da coisa vendida desaparecia, ainda que, na realidade, o objeto não tivesse perecido nem sido adquirido por outrem por usucapião ${ }^{2425}$.

Aqui também adquiriu relevo a influência exercida pelos canonistas, que acabaram por desenvolver um conceito muito lato de restituição, sobretudo a partir da proibição do Sétimo Mandamento: "não roubarás". Esta última expressão assumiu um significado cada vez mais amplo, que abarcava não apenas o apoderar-se ou reter ilegalmente bens tangíveis, mas também o "tomar" bens intangíveis, tais como a vida, a saúde, a honra, as expectativas de casamento etc.

Com São Tomás de Aquino ${ }^{30}$ a discussão desloca-se para o plano da justiça comutativa e esta transferência assume particular importância porque prepara o caminho para a incorporação da restituição no Direito Canônico, que terá influência decisiva sobre os demais ramos do Direito. Além de ter servido como ponto de partida para a compreensão da restituição como um problema eminentemente jurídico, a obra de Aquino contribuiu para a gradual afirmação de alguns dos dogmas atualmente dominantes, ao menos nos países da civil law.

Um desses dogmas consiste na limitação do dever de reparar pelo dano efetivamente causado a partir da colocação do problema em sede de justiça comutativa e de restauração de um equilíbrio, tornando mais óbvia a limitação da restituição à reposição do status quo ante e superando a idéia de que a restituição aparecia como um pressuposto da penitência, o que permitia, em algumas hipóteses, a exigência de um múltiplo do dano provocado.

É certo que S. TOMÁS DE AQUINO contempla e discute a possibilidade de nela se incorporar a restituição do lucro obtido pela interferência na esfera jurídica alheia, mas acaba por assumir uma posição moderada a este propósito, acentuando que, em muitas hipóteses, o lesado não poderia ter a certeza de obter esse lucro. Outro princípio fundamental vigente nos sistemas europeus-continentais é o do primado da restituição natural e também este parece encontrar aqui as suas raízes: a genuína restituição supõe a identidade material da coisa ou situação a restituir ${ }^{26}$.

\section{$\underline{\text { III.3 - A noção moderna de enriquecimento sem causa }}$}

\footnotetext{
24 “'...] tal é o caso quando, por exemplo, a reivindicação se transforma numa opção meramente teórica em razão dos mais diversos factores, como sejam, a distância a que o objeto se encontra ou a posição social de quem o detém que desaconselha o recurso aos tribunais". GOMES, Júlio Manuel Vieira. O conceito de enriquecimento, o enriquecimento forçado e os vários paradigmas do enriquecimento sem causa. Porto: Coimbra Editora, 1998, p. 25 . 30 AQUINO, Tomás de. Suma Teológica. II. II. São Paulo: Loyola, 2005.

. Porto: Coimbra Editora, 1998, pp. 69-70.
} 
Analisadas as origens do enriquecimento sem causa na tradição inglesa, romanista e canônica, cumpre tratar da concepção moderna de enriquecimento sem causa.

Mais uma vez, o primeiro diploma legal a ser enfocado consiste no Código Napoleão de 1804, que continuava, substancialmente, a mover-se na ótica dos remédios tradicionais romanos. O referido Código contemplava os institutos da repetição do indébito e da gestão de negócios. Não se distinguia claramente, pois, a ação de gestão de negócios e a de enriquecimento sem causa.

Aubry e Rau foram os primeiros a realizar tal distinção, afirmando que a ação de gestão de negócios pode ser utilizada apenas na presença do animus aliena negotia gerendi e que, por outro lado, o cabimento desta ação dispensa a verificação de uma utilidade efetiva da gestão (utiliter gestum), sendo suficiente que tenha sido eficientemente empreendida. Por outro lado, consideraram que a transferência de valor e a necessidade de um equilíbrio entre patrimônios representavam o verdadeiro fundamento da restituição fundada no enriquecimento sem causa.

Apesar disso, não tardou a Corte de Cassação Francesa em adotar os ensinamentos de Aubry e Rau. Isto se verificou no caso Arrêt Boudier. Um comerciante de adubo vendeu ao arrendatário de uma propriedade certa quantidade de seu produto e este se provou insolvente. Assim sendo, o comerciante ingressou em juízo em face do proprietário das terras arrendadas, que havia, seguramente, obtido um proveito desta situação. Os juízes da Corte de Cassação consideraram o proprietário responsável nos limites do enriquecimento efetivamente obtido. "In due sentenze successive del 1914 e del 1915, la Corte di Cassazione completò la formulazione dell'Arrêt Boudier, aggiungendo i due requisiti che ancora mancavano; vale a dire la mancanza di giusta causa, ed il carratere sussidiario dell'azione ${ }^{27}$ ".

Deste modo, o modelo francês da ação de enriquecimento sem causa passou a pressupor: enriquecimento, dano, correlação entre o dano e o enriquecimento, ausência de justa causa e subsidiariedade da ação.

O Código Civil italiano de 1942 enunciou como requisitos aqueles que já tinham sido individualizados pela jurisprudência franco-italiana: o enriquecimento; a falta de justa causa e a

\footnotetext{
${ }^{27}$ GALLO, Paolo. Introduzione al diritto comparato. v. II. Istituti giuridici. 2. ed. Torino: Giappichelli Editore, 2003, p. 224. 33 Melhor desenvolvendo o tema, afirma Paolo Gallo: "in base al modello franco-italiano l'azione di arrichiamento si fonda su cinque presupposti: a) l'arricchimento; b) il danno; c) uma correlazione sufficientemente prossima tra danno ed arricchimento; d) la mancanza di giustificazione dello spostamento patrimoniale; e) ed infine la carenza di altri rimedi specifici”. GALLO, Paolo. Introduzione al diritto comparato. v. II. Istituti giuridici. 2. ed. Torino: Giappichelli Editore, 2003, p. 229. 34 "La regola della sussidiarietà ha tratto origine nell'ambito del sistema francese, dove in conformità ai dettami della scuola dell'esegesi, si voleva escludere che un istituto di origine giurisprudenziale potesse modificare istituti previsti e disciplinati dal legisladore". GALLO, Paolo. Introduzione al diritto comparato. v. II. Istituti giuridici. 2. ed. Torino: Giappichelli Editore, 2003, p. 235.
} 


\section{Quaestio Iuris}

subsidiariedade da ação. O art. 2.041 do referido Código regulou, portanto, em termos muitos gerais a ação de enriquecimento sem causa, estabelecendo que qualquer pessoa que tenha enriquecido sem causa, à custa de outrem, deve, nos limites do enriquecimento obtido, indenizar este último que suportou a respectiva diminuição patrimonial. No artigo seguinte, aludiu o legislador italiano de forma expressa ao caráter subsidiário da ação ${ }^{33}$.

O Código Civil português optou também por atribuir natureza subsidiária à obrigação de restituir fundada no enriquecimento, esclarecendo em seu artigo $474^{\circ}$ que "não há lugar à restituição por enriquecimento, quando a lei facultar ao empobrecido outro meio de ser indenizado ou restituído, negar o direito à restituição ou atribuir outros efeitos ao enriquecimento" 34 .

Na doutrina alemã, deve-se a Puchta a afirmação de um ponto de vista em matéria de enriquecimento sem causa, que, posteriormente, foi melhor desenvolvido e refinado por Savigny.

Puchta considerava que uma condictio deveria ter lugar quando se verificasse a transferência de um elemento do patrimônio de um sujeito para o patrimônio de outro e, ao mesmo tempo, existisse um fundamento obrigacional que demandasse à restituição, pressupondo-se a impossibilidade de uma reivindicação. Este fundamento obrigacional poderia consistir no próprio contrato de mútuo ou em outro fundamento jurídico de modo que ab initio fosse possível identificar a falta de uma causa justificativa da transferência ou ainda que esta causa viesse a desaparecer posteriormente.

Já Savigny apresenta o enriquecimento sem causa como uma unidade e considera que os casos de enriquecimento têm a ver com situações em que se verifica um acréscimo de um patrimônio através da diminuição de um outro patrimônio, acréscimo este sem fundamento ou cujo fundamento desaparece ulteriormente. Deste modo, torna-se necessário, para que a restituição seja exigível, que o que serviu ao enriquecimento de um existisse já, previamente, no patrimônio de outrem.

Schulz, ao seu turno, busca, após a entrada em vigor do BGB, reconduzir a obrigação de restituir ao conceito de lesão de um direito. Segundo este autor, na base da obrigação de restituir estava a comissão de um ilícito ou uma ingerência não autorizada no direito de outrem.

Por intervenção entende este autor qualquer atuação com reflexos em um direito alheio no contexto em que ele existe, seja através da destruição do direito em questão seja através da alteração da relação jurídica. "Representa, assim, uma intervenção na propriedade alheia a 


\section{Quaestio Iuris}

simples subtracção da posse, já que, a propriedade desacompanhada da posse é uma realidade diversa da propriedade que coexiste com a posse ${ }^{28} \%$

A existência de uma intervenção, de um resultado e do referido nexo de causalidade são os pressupostos constantes do direito ao produto desta intervenção. Adicionalmente, e em decorrência das circunstâncias do caso, podem ser exigidos um ou vários dos seguintes pressupostos: ilicitude da intervenção e culpa do interventor. Quanto ao dano do lesado, este não se verifica relevante na construção de Schulz, já que a limitação do direito ao lucro da intervenção pelo dano do lesado converteria tal direito em uma forma menor de responsabilidade civil.

O princípio fundamental para Schulz residia no fato de que ninguém deve poder retirar um lucro de uma intervenção ilícita em um direito alheio.

Trata-se, como este mesmo autor reconhece, de uma ampliação do pensamento que tradicionalmente subjaz à restituição fundada no enriquecimento sem causa e, por isso mesmo, de uma proposição mais ambiciosa. Esta proposta representava,

também, como o seu autor expressamente sublinhou, de algum modo uma inversão do princípio basilar que preside à reparação do dano na responsabilidade civil: neste direito ao produto da intervenção o que está em causa não é o património do titular do direito, mas, em primeira linha, o património do autor na intervenção ${ }^{29}$.

O pensamento de Schulz sofreu forte crítica de Francisco Manuel Pereira Coelho ${ }^{30}$, que considera inaceitável tal posição, tanto no geral como no plano do direito português, uma vez que concede uma proteção excessiva ao titular do direito e soluciona o conflito de interesses entre o titular do direito e o interventor de maneira "parcial", conferindo uma proteção excessiva daquele. Tratar-se-ia, pois, de uma medida punitiva que se traduziria em um autêntico confisco, em uma reação penal contra a ação ilícita do interventor, constituindo verdadeira pena privada.

Revelou-se ainda fundamental para a compreensão moderna do enriquecimento sem causa na Alemanha, o trabalho de Wilburg ${ }^{31}$, posteriormente aperfeiçoado por Von Caemmerer $^{32}$, que sustentava que a ocorrência de um dano e o caráter direto ou imediato entre

\footnotetext{
28 . Porto: Coimbra Editora, 1998, p. 181.

${ }^{29}$ GOMES, Júlio Manuel Vieira. O conceito de enriquecimento, o enriquecimento forçado e os vários paradigmas do enriquecimento sem causa. Porto: Coimbra Editora, 1998, pp. 182-183.

${ }^{30}$ COELHO, Francisco Manuel Pereira. O enriquecimento e o dano. Coimbra: Almedina, 1999.

${ }^{31}$ WILBURG, Walter. Die Lehre von der ungerechtfertigten Bereicherung nach österreichischem und deutchem Recht, Kritik und Aufbau. Graz: Leuschner \& Lubensky, 1934.

${ }^{32}$ VON CAEMMERER, Ernst. "Bereicherung und unerlaubte Handlung” in Gesammelte Schriften. vol. I. Tübingen: Mohr, 1968, pp. 209 e segs.
} 


\section{Quaestio Iuris}

vol.04, n0.01. ISSN 1516-0351

o dano e a vantagem do enriquecido eram desnecessários e, mesmo, perniciosos para a compreensão do enriquecimento sem causa. Essencial, nesta linha, é saber quando é que um enriquecimento é injustificado. Referindo-se à expressão de Pomponius, segundo a qual "ninguém se deve enriquecer com o dano alheio", sublinha o autor que ela é, por um lado, demasiadamente abrangente e, por outro, excessivamente restrita. Quanto ao primeiro aspecto, na vida cotidiana, verificam-se muitas situações em que, como é próprio de uma economia de mercado, uma pessoa se enriquece à custa de outrem sem que, por isso, o enriquecimento seja ilícito. Assim sendo, quando alguém obtém uma vantagem à custa de outrem, a questão que importa colocar não é a de saber se existe uma causa de justificação desse enriquecimento, mas, ao invés, a de saber se existe algum fundamento para considerar o enriquecimento injustificado. Quanto ao segundo aspecto, um enriquecimento pode ser injustificado, mesmo em situações em que não existe dano alheio.

$\mathrm{Na}$ esteira de WILBURG e de VON CAEMMERER, a opinião largamente dominante na Alemanha é aquela que nega, radicalmente, a unidade do instituto e contradistingue o enriquecimento obtido através de uma prestação e o obtido "por outro modo". Naquele primeiro domínio, o enriquecimento sem causa tem como escopo "desfazer" ou "inverter" uma prestação [...], sendo que a falta de causa consiste, para a doutrina germânica maioritária, na frustração do fim visado com a realização da prestação. De entre as várias modalidades do enriquecimento obtido "de outro modo", avulta, pela sua importância, o enriquecimento resultante de uma intromissão ou ingerência na esfera jurídica alheia ${ }^{33}$.

Percebe-se, deste modo, que o modelo alemão e também o anglo-americano consideram suficiente que o enriquecimento decorra de uma ingerência não consentida na esfera de proteção de outrem. Mais do que isso, o enriquecimento sem causa se verificaria na hipótese em que alguém obtivesse proveito a partir de recursos que, pelo menos em parte, pertencessem a outrem.

Neste particular, adquire relevo o ordenamento inglês que sustenta ser possível restar configurada a obtenção de um benefício pelo simples fato de ter induzido outrem a adotar certo comportamento por acreditar em uma realidade de fato inexistente. Em outras palavras, seria suficiente que alguém induzisse outrem a realizar uma determinada prestação, sendo desnecessária a ocorrência de um efetivo enriquecimento.

\footnotetext{
${ }^{33}$ GOMES, Júlio Manuel Vieira. O conceito de enriquecimento, o enriquecimento forçado e os vários paradigmas do enriquecimento sem causa. Porto: Coimbra Editora, 1998, p. 197.
} 
Também no âmbito do ordenamento alemão a teoria do proveito criado tem adquirido importância, já que, modernamente, o proveito não é a conseqüência de uma verdadeira transferência patrimonial, mas sim o fruto de uma criação autônoma.

In tempi più recenti la teoria del profitto creato há ricevuto um importante riconoscimento da parte del $\S 812 \mathrm{BGB}$, il quale nella sua redazione definitiva utilizza l'espressione auf dessen Kosten in luogo dell'espressione aus dessen Vermögen precedentemente proposta; proprio allo scopo di sottolineare come ai fini della configurabilità dell'azione di arrichiamento non sai necessário un danno in senso próprio dell'espressione, e tanto meno un vero e proprio trasferimento di richezza, ma piuttosto che qualcuno sai riuscito a realizzare um guadagno mettendo a profitto risorse altrui ${ }^{34}$.

Assim sendo, nos sistemas alemão e anglo-americano, é preferível aludir à expressão prejuízo a referir-se a dano, já que não se perquire para a configuração do enriquecimento sem causa a verificação de uma perda patrimonial, mas sim a ocorrência de um fato que acarrete lesão ao direito ou situação protegida de outrem.

\footnotetext{
${ }^{34}$ GALLO, Paolo. Introduzione al diritto comparato. v. II. Istituti giuridici. 2. ed. Torino: Giappichelli Editore, 2003, p. 232. 42 "O tratamento dado pelo CC ao locupletamento injustificado consiste em uma novidade legislativa, já que o CC1916 não dispôs sobre esta figura através de uma regra geral, disciplinando apenas o pagamento indevido. Porém, em dispositivos pontuais, a projeção do princípio de proibição ao enriquecimento sem causa podia ser vislumbrada, como nos casos dos arts. 307, 513, 516, 519, 546, 936, in fine, 1.278, 1.339, todos do CC 1916 (Silvio Rodrigues, Direito Civil, p. 419).

Na doutrina, o acolhimento da vedação do locupletamento injustificado como princípio era motivo de divergências. Por um lado, afirmava-se que o CC1916 'não considerou o enriquecimento ilícito como figura especial de obrigação, ou como causa geradora de obrigação, porque suas diversas formas não se subordinam a um princípio unificador (...). Cada uma das formas por ele apresentada aparecerá em seu lugar (Clovis Bevilaqua, Código Civil, p. 97).

No entanto, na vigência do código revogado também já havia entendimento de que, embora não contido numa regra geral, a vedação ao enriquecimento injustificado consistia num princípio geral do direito brasileiro (Agostinho Alvim. "Do Enriquecimento sem Causa", p. 22)". TEPEDINO, Gustavo; BARBOZA, Heloisa Helena; MORAES, Maria Celina Bodin de. Código Civil Interpretado. vol. II. Rio de Janeiro: Renovar, 2006, pp. 750751. 43

TEPEDINO, Gustavo; BARBOZA, Heloisa Helena; MORAES, Maria Celina Bodin de. Código Civil Interpretado. vol. II. Rio de Janeiro: Renovar, 2006, p. 753.

44 TEPEDINO, Gustavo; BARBOZA, Heloisa Helena; MORAES, Maria Celina Bodin de. Código Civil

Interpretado. vol. II. Rio de Janeiro: Renovar, 2006, p. 753. É alvissareiro também mencionar que, “ainda quando o enriquecimento não tem por objeto coisa determinada, se prioriza o ressarcimento in natura, de maneira a garantir a restituição justa do que foi indevidamente auferido (Júlio Manuel Vieira Gomes, O Conceito de Enriquecimento, pp. 105-106). Com mais razão, esta regra aplica-se em caso de enriquecimento que tem por objeto coisa determinada - como resta positivado no parágrafo único do dispositivo em exame.

Porém, para que seja possível esse tipo de restituição, é necessário que a coisa subsista na época da sua devolução. Ocorre que, em muitos casos, a coisa se perdeu ou deteriorou. O CC determina que, nessas hipóteses, a restituição se faça pelo valor do bem na época em que foi exigido". TEPEDINO, Gustavo; BARBOZA, Heloisa Helena; MORAES, Maria Celina Bodin de. Código Civil Interpretado. vol. II. Rio de Janeiro: Renovar, 2006, p. 753. 45

VENOSA, Sílvio de Salvo. "O enriquecimento sem causa no Novo Código Civil". Disponível em: http://jfms.jusbrasil.com.br/noticias/159512/o-enriquecimento-sem-causa-no-novo-codigo-civil. Acesso em: 17 de março de 2012.
} 
No âmbito do ordenamento pátrio, o enriquecimento sem causa foi disciplinado no Código Civil de 2002, mais especificamente, no art. $884^{42}$ :

Aquele que sem justa causa, se enriquecer à custa de outrem, será obrigado a restituir
o indevidamente auferido, feita a atualização dos valores monetários."
Parágrafo único. Se o enriquecimento tiver por objeto coisa determinada, quem a
recebeu é obrigado a restituí-la, e, se a coisa não mais subsistir, a restituição se fará
pelo valor do bem na época em que foi exigido.

Deste modo, a previsão do referido Código é que há enriquecimento sem causa com obrigação de restituir nas hipóteses de inexistência de causa jurídica para o enriquecimento de um e o empobrecimento de outro ou a causa para enriquecimento deixou de existir.

Nesta esteira, assevera Gustavo Tepedino que o primeiro requisito a ser aqui perquirido é o enriquecimento, isto é, a existência de uma melhora na situação patrimonial da pessoa obrigada a restituir. O enriquecimento, contudo, não se verifica apenas mediante um aumento no ativo, podendo ocorrer também por uma diminuição do passivo, como o pagamento de dívida alheia, ou mesmo através da poupança de uma despesa, como no enterro realizado pelo gestor de negócios.

Já o segundo requisito é que o enriquecimento se dê à custa de outrem. O termo "empobrecimento" é normalmente rejeitado por remeter à idéia de diminuição no patrimônio do titular do direito à restituição, o que não precisa ocorrer, "como no exemplo de Antunes Varela, daquele que utiliza cavalo alheio para ganhar uma corrida da qual o dono do cavalo não participaria $^{43}$ ".

\section{Saliente ainda Tepedino que}

Alguns autores cogitam de um nexo de causalidade entre o enriquecimento e o dito "empobrecimento", isto é, que se dê à custa de outrem (Giovanni Ettore Nanni, Enriquecimento sem causa, p. 250). Todavia, não se revela necessário que haja uma relação direta entre enriquecimento e empobrecimento. É necessário apenas que estejam relacionados o fato que gerou o enriquecimento com o empobrecimento ou, se ele não se afigurar, com o suporte correspondente à custa de outrem (Mário Júlio de Almeida Costa. Direito das Obrigações, p. 429). Não há uma relação de causa e efeito entre enriquecimento e empobrecimento; o que deve haver é uma interdependência em virtude de um fato originário em comum, que causou ambos - o

que se tem chamado de indivisibilidade de origem (Agostinho Alvim, "Do enriquecimento sem causa", p. 59) ${ }^{44}$. 
É importante salientar que a ação de enriquecimento sem causa será sempre subsidiária, conforme prevê o artigo 886 do Código Civil, que estabelece que "não caberá a restituição por enriquecimento, se a lei conferir ao lesado outros meios para se ressarcir do prejuízo". Assim sendo, não caberá ação de locupletamento se for possível mover a de cobrança baseada em contrato ou indenizatória por responsabilidade civil em geral.

\begin{abstract}
Desse modo, é possível, em princípio, promover uma ação de enriquecimento sem causa em todas as situações nas quais não é mais possível promover a ação específica, por ter decorrido o prazo prescricional. Como enfatizado, a ação de locupletamento indevido é subsidiária, isto é, a última de que pode se valer o credor perante a inexistência de qualquer outro meio jurídico. Os efeitos da ação de enriquecimento serão sempre menores do que os da ação derivada de um contrato ou da responsabilidade aquiliana. $\mathrm{Na}$ primeira, apenas a efetiva perda ou empobrecimento poderá ser concedido; nas outras, pode-se falar em indenização equivalente a prestações não cumpridas, cláusula penal e perdas e danos. Não pode, é evidente, a ação de enriquecimento converter-se em uma panacéia jurídica. Contudo, trata-se de um instrumento importante para a recuperação de créditos que já se julgam perdidos por força de uma prescrição.

Note que, a exemplo da ação de enriquecimento relacionada com os títulos de crédito, o prazo prescricional para a ação de enriquecimento sem causa é de três anos, conforme prevê o artigo $\underline{206}$, parágrafo $3^{\circ}$, inciso IV do novo Código Civil . Esse prazo, seguindo o princípio da "actio nata", começa a fluir a partir do momento em que as outras ações não podem mais ser propostas, como examinamos - a partir, portanto, do escoamento do prazo prescricional da ação derivada do contrato ou de outro ato ou negócio jurídico ${ }^{45}$.
\end{abstract}

\title{
III. 4 - A quantificação da obrigação a ser restituída
}

Uma vez definida a ocorrência de uma das fattispecies de enriquecimento sem causa em todos os seus aspectos, surge um problema de quantificação da obrigação de restituir.

Existem duas alternativas fundamentais no que diz respeito à quantificação da obrigação a ser restituída: impor a devolução apenas do valor subtraído ou impor a devolução do inteiro proveito obtido de forma injusta.

Neste particular, afirma Paolo Gallo, no bojo da doutrina italiana, que:

In linea di massima può però dirsi che mentre in presenza di buona fede l'obligo restitutorio è normalmente limitato al solo valore oggetivamente sottrato; se vi è mala fede, le corti mostrano più propensione a configurare obbligi restitutori integrali.

Nei paese di common law l'entità dell'obbligazione restitutoria viene normalmente commisurata al valore oggetivamente sottrato, o al risparmio di spesa effetuato. Vi sono però anche casi nei quali è prevista la devoluzione integrale dei profitti realizzati (accounting of profits). 
Si tratta di um rimedio d'equity, il quale al pari di tutti gli altri rimedi amministrati dal cancelliere è del tutto discrezionale ${ }^{35}$.

Contudo, a restituição integral do proveito obtido é considerada excepcional e, apenas na presença de circunstâncias específicas, pode ser justificada. Na jurisprudência, restou assente que somente nas hipóteses de má fé ou de um comportamento culpável (schuldhaft) é possível configurar uma obrigação restituitória integral.

Aqui entram em cena as figuras da gestão de negócios e da responsabilidade civil. Conforme decisões proferidas, no decorrer do século XIX, pelo Reichsgericht, em certos casos, a lesão a bens imateriais abria a possibilidade de requerer a restituição integral dos proveitos realizados sob os auspícios das normas referentes à gestão de negócios. Uma segunda via para obtenção da restituição integral dos proveitos obtidos, na Alemanha, residia na responsabilidade civil.

Foram, assim, previstos três métodos de quantificação do dano: o ressarcimento do dano efetivamente sofrido, a devolução de uma soma correspondente às despesas realizadas ou, ainda, a devolução integral do proveito obtido.

Neste ponto, a doutrina sustenta que, somente o reconhecimento de uma obrigação de restituir integralmente o proveito obtido, pode ter o condão de evitar que tal comportamento lesivo se repita ${ }^{47}$.

Por outro lado, se considera que se deve também tutelar e incentivar os comportamentos ativos, que objetivem a obtenção de um proveito.

Na opinião de Paolo Gallo, uma forma de compatibilizar estes dois reclamos residiria na configuração de uma obrigação de natureza restituitória integral somente nos casos de má fé é $^{36}$, já que apenas a constatação de dolo poderia justificar a aplicação de sanções civis ${ }^{49}$.

Sílvio de Salvo Venosa, ao seu turno, sustenta, no âmbito da doutrina pátria, que a ${ }^{37}$ restituição que se almeja na ação de enriquecimento sem causa deve ficar entre dois parâmetros: de um lado não pode ultrapassar o enriquecimento efetivo recebido pelo agente em detrimento do devedor e, de outro, não pode ultrapassar o empobrecimento do outro agente, isto é, o montante em que o patrimônio sofreu diminuição, quando tal hipótese se verificar ("teoria do duplo limite"). Não se trata, portanto, de efeitos que se assemelhem a uma ação de

\footnotetext{
${ }^{35}$ GALLO, Paolo. Introduzione al diritto comparato. v. II. Istituti giuridici. 2. ed. Torino: Giappichelli Editore, 2003, p. 239. 47 SACCO, Rodolfo. L'arricchimento ottenuto mediante fatto ingiusto: contributo alla teoria della responsabilità estracontrattuale. Torino: Unione tipografico-editrice torinense, 1959.

${ }^{36}$ TRIMARCHI, Pietro. L'arricchimento senza causa. Milano: Giuffrè, 1962

${ }^{37}$ GALLO, Paolo. Pene private e responsabilità civile. Milano: Giuffrè, 1986.
} 


\section{Quaestio Iuris}

vol.04, n0.01. ISSN 1516-0351

nulidade ou de resolução de negócio jurídico. Também não se cuida de estabelecer uma indenização, mas de uma reparação na medida do enriquecimento, na medida do pagamento, por exemplo, que deveria ter sido efetuado e não o foi ${ }^{38}$.

Afirma Gustavo Tepedino que o parágrafo único do art. 884

Visa a ressarcir o empobrecido do valor da coisa na época em que ele resolve "reivindicá-la" através da ação in rem verso. Não obstante, esta solução poderia configurar uma situação de extrema injustiça no caso do enriquecido de boa-fé, que jamais soube que seu enriquecimento se fazia à custa de outrem.

Portanto, este artigo deve ser interpretado com cautela para que, no desiderato de ressarcir o empobrecido, não se cause um empobrecimento desmedido e injustificado àquele que enriqueceu de boa-fé. "Assim, ele apenas terá que restituir na medida em que o seu enriquecimento subsista e, neste contexto, é que cumpre atender às consequiências que o obtido teve no seu patrimônio, limitando-se a sua obrigação de restituir ao enriquecimento patrimonial subsistente" (Júlio Manuel Vieira Gomes, O Conceito de Enriquecimento, p. 117) ${ }^{39}$.

Acerca da quantificação da obrigação a ser restituída, é alvissareira a transcrição da seguinte ementa:

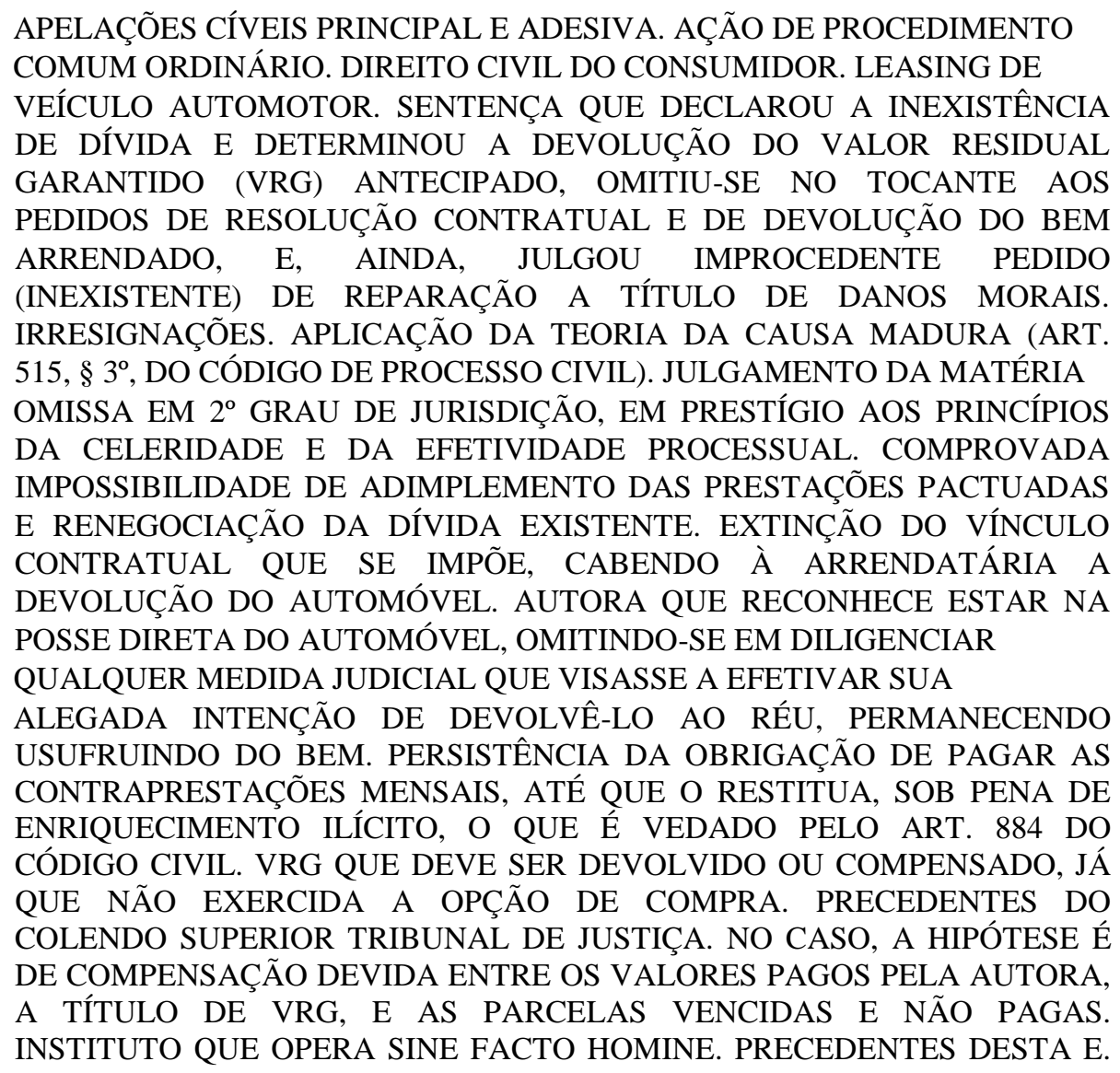

${ }^{38}$ VENOSA, Sílvio de Salvo. “O enriquecimento sem causa no Novo Código Civill”. Disponível em: http://jfms.jusbrasil.com.br/noticias/159512/o-enriquecimento-sem-causa-no-novo-codigo-civil. Acesso em: 17 de março de 2012.

${ }^{39}$ TEPEDINO, Gustavo; BARBOZA, Heloisa Helena; MORAES, Maria Celina Bodin de. Código Civil Interpretado. vol. II. Rio de Janeiro: Renovar, 2006, p. 754. 
CORTE ESTADUAL. RECURSO PRINCIPAL A QUE SE DÁ PARCIAL PROVIMENTO, PARA DETERMINAR QUE O VALOR DO VRG ANTECIPADO SEJA COMPENSANDO COM O VALOR DAS PARCELAS VENCIDAS, DESCONTANDO-SE O VRG SOBRE ELAS INCIDENTE, E NÃO PAGAS, COM JUROS E CORREÇÃO MONETÁRIA, DESDE CADA VENCIMENTO, ATÉ A DEVOLUÇÃO DO VEÍCULO. APELO ADESIVO A QUE SE DÁ PARCIAL PROVIMENTO PARA DETERMINAR QUE OS VALORES PAGOS A TÍTULO DE VRG SEJAM DEVOLVIDOS ACRESCIDOS DE CORREÇÃO MONETÁRIA A PARTIR DE CADA DESEMBOLSO, MANTIDOS OS JUROS LEGAIS DESDE A CITAÇÃO. ART. 557, § 1. ․ $^{-}$, DO CÓDIGO DE PROCESSO CIVIL, C/C ENUNCIADO N. ${ }^{\circ} 65$ DO AVISO TJ N. ${ }^{\circ}$ 52/2011. CASSAÇÃO, DE OFÍCIO, DO CAPÍTULO DA SENTENÇA QUE JULGOU IMPROCEDENTE PEDIDO (INEXISTENTE) DE COMPENSAÇÃO POR DANOS MORAIS. EQUIVOCADA SUCUMBÊNCIA RECÍPROCA, QUE SOMENTE ESXURGE COM ESTA DECISÃO. TAXA JUDICIÁRIA E AS CUSTAS PROCESSUAIS SERÃO RATEADAS E OS HONORÁRIOS ADVOCATÍCIOS, COMPENSADOS, OBSERVADA, EM RELAÇÃO À AUTORA, A CONDIÇÃO SUSPENSIVA DO ARTIGO 12 DA LEI

1.050/60 (TJ-RJ, Décima Oitava Câmara Cível, Apelação 000024779.2010.8.19.0210, Des. Gilberto Guarino, Julgamento: 10/03/2012) (Grifei) ${ }^{40}$.

$\underline{\text { IV - Conclusão }}$

Conforme já mencionado, comparar não significa fotografar diferentes realidades e colocá-las em confronto, mas sim estudá-las no decorrer de seus desenvolvimentos, nas suas trocas e inter-relações.

Este foi o objetivo precípuo deste trabalho ao enfocar o enriquecimento sem causa, analisado sob uma perspectiva histórica e, sobretudo, comparada.

Para tanto, realizou-se uma análise preliminar da responsabilidade por inadimplemento a partir da concepção trazida pelo Jusnaturalismo de que "nenhuma responsabilidade sem

\footnotetext{
${ }^{40}$ Interessante notar que o enriquecimento sem causa é utilizado, pela jurisprudência pátria, como critério delimitador do montante a ser pago quando da veiculação de pretensões indenizatórias, sobretudo, a título de danos morais. Neste sentido, segue a ementa: "APELAÇÃO CÍVEL. RESPONSABILIDADE CIVIL. EMPRÉSTIMOS CONSIGNADOS. NÃO RECONHECIMENTO. FALHA NA PRESTAÇÃO DO SERVIÇO. DANO MORAL CONFIGURADO. Empréstimos descontados em contracheque não contratados pela autora. Falha na prestação do serviço que se verifica. Risco do empreendimento do fornecedor do serviço. Devida condenação ao pagamento de indenização a título de dano moral. Consoante é cediço, em nosso ordenamento jurídico não há limite legal prefixado ou tabela tarifada a ser observada pelo Juiz para a valoração do dano moral. Todavia, seu valor deve ser sempre arbitrado com fulcro nos princípios gerais da razoabilidade, da proporcionalidade e da vedação do enriquecimento sem causa, buscando-se, assim, que a verba indenizatória seja estipulada em montante suficiente para compensar o dano, sem, contudo, configurar-se como fonte de lucro para o ofendido. Verifica-se que o valor arbitrado pela douta julgadora de primeira instância em $\mathrm{R} \$ 5.000,00$ (cinco mil reais) revela-se perfeitamente justo e suficiente para a reparação dos danos morais pleiteados pelo autor. Juros de mora sobre o dano moral que devem incidir a partir do ato ilícito, ou seja, dos descontos indevidos. RECURSO AO QUAL SE NEGA SEGUIMENTO, NOS TERMOS DO ART. 557, CAPUT CPC". (TJ-RJ, Segunda Câmara Cível, Apelação 001624134.2011.8.19.0204, Des. Elisabeth Filizzola, Julgamento: 01/03/2012) (Grifei).
} 


\section{Quaestio Iuris}

culpa”. Este princípio foi concebido para qualquer tipo de responsabilidade, isto é, tanto para o ilícito civil como para o inadimplemento contratual. O primeiro diploma legal enfocado foi o

Código Napoleão que ditou normas apenas parcialmente coerentes com este princípio. A seguir, analisou-se a responsabilidade contratual no ordenamento jurídico alemão, que tem como ponto de partida o sistema das Leistungsstörungen, isto é, baseia-se naqueles eventos que obstaculizam a exata execução da prestação e impedem ao credor obter sua pretensão. Viu-se ainda que, no sistema da common law, a responsabilidade contratual assumiu diferente feição, isto porque a contract liability delimitou um campo não totalmente coincidente com a responsabilidade contratual. Desta forma, constatou-se que a contract liability surgiu como uma breach of contract, ou seja, como o não cumprimento de um contrato e, em especial, com o não cumprimento de uma promessa contratual expressa ou ainda com o não cumprimento do dever de executar o contrato conforme a boa fé.

A importância desta abordagem primeira residiu no fato de que ela possibilitou enfocar o nascimento dos "quase-contratos" ingleses, que, por sua vez, permitiram transcender as noções de breach of contract e de responsabilidade civil clássica, contribuindo para a construção da noção de enriquecimento sem causa. Isto porque, como já mencionado, os "quase-contratos" ingleses se referiam a acordos imperfeitos que, pela carência de um qualquer requisito considerado essencial, não podiam ser considerados idôneos a gerar um vínculo válido entre as partes.

Enfocou-se ainda o contributo do direito romano clássico para a formação desta noção de enriquecimento ilícito, embora não existisse uma ação de enriquecimento sem causa comparável à moderna naquele sistema. Existiam, por outro lado, vários remédios de natureza "quase-contratual", como a condictio, a negotiorum gestio e a actio in rem verso.

Salientou-se também a importância da obra dos compiladores bizantinos e da influência exercida pelos pós-glosadores e canonistas para a compreensão do enriquecimento sem causa. Neste particular, adquiriu especial relevo a posição de São Tomás de Aquino, já que, com ele, a discussão desloca-se para o plano da justiça comutativa e esta transferência prepara o caminho para a incorporação da restituição no Direito Canônico, que terá influência decisiva sobre os demais ramos do Direito.

Por fim, tratou-se da noção moderna de enriquecimento sem causa. Mais uma vez, o primeiro diploma legal enfocado foi o Código Napoleão de 1804, que continuava, substancialmente, a mover-se na ótica dos remédios tradicionais romanos. O referido Código 


\section{Quaestio Iuris}

contemplava os institutos da repetição do indébito e da gestão de negócios, embora não distinguisse claramente a ação de gestão de negócios e a de enriquecimento sem causa. Aubry e Rau foram os primeiros a realizar tal distinção e, a partir daí, o modelo francês da ação de enriquecimento sem causa passou a pressupor: enriquecimento, dano, correlação entre o dano e o enriquecimento, ausência de justa causa e subsidiariedade da ação. O Código Civil italiano de 1942, seguindo nesta esteira, enunciou como requisitos o enriquecimento; a falta de justa causa e a subsidiariedade da ação e o Código Civil português optou também por atribuir natureza subsidiária à obrigação de restituir fundada no enriquecimento.

Já na doutrina alemã, verificou-se que se deve a Puchta a afirmação de um ponto de vista em matéria de enriquecimento sem causa. Além do referido autor, aludiu-se às contribuições de Savigny, de Schulz e, principalmente, de Wilburg, já que o trabalho deste último, posteriormente aperfeiçoado por Von Caemmerer, conduziu à concepção de que a ocorrência de um dano e o caráter direto ou imediato entre o dano e a vantagem do enriquecido eram desnecessários e, mesmo, perniciosos para a compreensão do enriquecimento sem causa. A partir de então, essencial passou a ser identificar quando é que um enriquecimento é injustificado.

Através desta digressão, foi possível melhor compreender os contornos do enriquecimento sem causa no âmbito do ordenamento pátrio. Disciplinado no Código Civil de 2002, mais especificamente, no art. 884, verifica-se o enriquecimento sem causa nas hipóteses de inexistência de causa jurídica para o enriquecimento de um e o empobrecimento de outro ou a causa para enriquecimento deixou de existir. Congregam-se, desta forma, traços das concepções franco-italiana - que exige, para configuração do enriquecimento ilícito, o enriquecimento, a falta de justa causa e a subsidiariedade da ação - e tedesca, já que, por outro lado, não se reclama a ocorrência de um dano e o caráter direto ou imediato entre o dano e a vantagem do enriquecido.

Por fim, quanto à quantificação da obrigação a ser restituída, a partir da análise da doutrina estrangeira e, sobretudo, pátria, restou patente a distinção entre a responsabilidade civil e o enriquecimento sem causa, já que, enquanto a primeira confere uma proteção dinâmica a partir do princípio do neminem laedere e visa ao ressarcimento integral do dano sofrido pela vítima, o segundo oferece apenas uma proteção estática ao patrimônio, abrangendo casos não cobertos pela responsabilidade civil, como quando não há ilicitude ou dano. Desta forma, na 


\section{Quaestio Iuris}

aplicação do instituto do enriquecimento sem causa restou patente que o objetivo não é reparar o dano, mas forçar o beneficiário a restituir o indevidamente locupletado.

\section{$\underline{\text { IV - Referências }}$}

AQUINO, Tomás de. Suma Teológica. II. II. São Paulo: Loyola, 2005.

COELHO, Francisco Manuel Pereira. O enriquecimento e o dano. Coimbra: Almedina, 1999.

DAVID, René. Traité élémentaire de Droit Civil Compare: introduction à l'étude des droits étrangers et à la méthode comparative. Paris, 1950.

GALGANO, Francesco. Atlas de Derecho privado comparado. Madri: Fundación Cultural del Notoriado, 2000.

GALLO, Paolo. Introduzione al diritto comparato. v. II. Istituti giuridici. 2. ed. Torino: Giappichelli Editore, 2003.

GALLO, Paolo. "La recezione dei modelli continentali nel diritto inglese delle obbligazioni" in Studi Sacco. vol. I. Milano. 1994.

GALLO, Paolo. Pene private e responsabilità civile. Milano: Giuffrè, 1986.

GEROTA, Demètre G. La théorie de l'enrichissement san cause dans le Code Civil allemand. Paris: LGDJ, 1925.

GOMES, Júlio Manuel Vieira. O conceito de enriquecimento, o enriquecimento forçado e os vários paradigmas do enriquecimento sem causa. Porto: Coimbra Editora, 1998.

SACCO, Rodolfo. L'arricchimento ottenuto mediante fatto ingiusto: contributo alla teoria della responsabilità estracontrattuale. Torino: Unione tipografico-editrice torinense, 1959. 
TEPEDINO, Gustavo; BARBOZA, Heloisa Helena; MORAES, Maria Celina Bodin de.

Código Civil Interpretado. vol. II. Rio de Janeiro: Renovar, 2006.

TRIMARCHI, Pietro. L'arricchimento senza causa. Milano: Giuffrè, 1962.

VENOSA, Sílvio de Salvo. “O enriquecimento sem causa no Novo Código Civill”. Disponível em: http://jf-ms.jusbrasil.com.br/noticias/159512/o-enriquecimento-sem-causa-no-novocodigocivil. Acesso em: 17 de março de 2012.

VON CAEMMERER, Ernst. "Bereicherung und unerlaubte Handlung” in Gesammelte Schriften. vol. I. Tübingen: Mohr, 1968.

WILBURG, Walter. Die Lehre von der ungerechtfertigten Bereicherung nach österreichischem und deutchem Recht, Kritik und Aufbau. Graz: Leuschner \& Lubensky, 1934.

ZWEIGERT, KÖTZ. Einführung in die Rechtsvergleichung auf dem Gebiete des Privat-rechts, 2 vol, Tubinga, 1969, 1971; $2^{\text {a }}$ ed., 1984; $3^{\text {a }}$ ed., 1996. 